\title{
Influence of quality public lighting on road safety
}

\begin{abstract}
Society for development of public lighting in cooperation with headquarters of traffic police of Czech Republic and with Ministry of Transport of Czech Republic and with BESIP continues with verifying the results of the study of impacts of public lighting on traffic safety in regions road passages - roads of I class to III class in urban areas. The standards for public lighting of road passage are compulsory but very often neglected. There are no defenders of quality-made road lighting. Because public lighting of road urban passage belongs to local town/village, there are being realized such projects under energy savings that are decreasing the traffic safety in such town/village. Towns are saving and people are dying.
\end{abstract}

Keywords: public lighting quality, traffic accidents, transit road sections

\section{Veřejné osvětlení}

Veřejné osvětlení je důležitou a nedílnou součástí technické infrastruktury obcí a měst, která slouží nejenom uživatelům pozemních komunikací uvnitř intravilánu, ale také obyvatelům těchto obcí a měst. Veřejné osvětlení tak tvoří jeden $z$ důležitých piliřru bezpečného dopravního prostoru v nočním prostředí.

\section{Opora kvalitního veřejného osvětlení v legislativě}

Kvalita staveb je zakotvena ve stavebním zákoně [1]. V souladu s ustanovením $\$ 169$ odst. 1 zákona 183/2006 Sb. jsou i orgány veřejné správy povinny respektovat obecné požadavky na výstavbu stanovené prováděcími právními předpisy. Ke stanovení technických požadavků pro stavby dálnic, silnic, místních komunikací a veřejně prístupných účelových komunikací je zmocněno ministerstvo dopravy (§194 písm. c) zákona 183/2006 Sb.).

Vyhláška zpracovaná Ministerstvem dopravy č.104/1997 Sb. [2], kterou se provádí zákon o pozemních komunikacích, hovoří velmi jasně. Podle ustanovení §25 se dálnice a silnice vždy osvětlují v zastavěném území obcí. Mimo toto území se osvětlují jen zvlášt' určené úseky, jako např. na hraničních přechodech, $v$ tunelech a na jejich přilehlých úsecích, výjimečně na křižovatkách, za podmínek obsažených v závazných ČSN 736102 a ČSN 737507. Podle výše uvedeného by se zdálo, že je všechno $v$ naprostém pořádku. Zásadní rozkol do tohoto téměř ideálního stavu vnáší ustanovení §14, odst.1, písm. b) zákona o pozemních komunikacích 13/1997 Sb., které vložilo vlastnictví veřejného osvětlení do rukou obce - tedy subjektu, který není ze zákona zodpovědný za kvalitní osvětlení dopravního prostoru dálnic/silnic (tedy průjezdních úseků silnic). Skutečnost, že veřejné osvětlení není příslušenstvím dálnice/silnice $v$ zastavěném území obce, resp. že může patřit jinému subjektu, než vlastníkovi těchto komunikací, má zásadní význam pro príčitatelnost povinnosti péče o pozemní komunikace (včetně povinnosti osvětlování dálnic a silnic v zastavěném území obce). K tomuto tématu je v časopise Světlo 6/2013 v článku „Veřejné osvětlení a obec pod lupou zákona“ autorů JUDr. Tomáše Sequense, JUDr. Petry Novákové, Ph.D., JUDr. Richarda Hamrana, uvedeno: „Tato povinnost, jejíž podrobnosti stanoví prováděcí vyhláška k zákonu o pozemních komunikacích, tíží z povahy věci zásadně vlastníka pozemních komunikací. Problémy v tomto ohledu zřejmě nečiní situace, kdy vlastník pozemní komunikace současně vlastní i veřejné osvětlení. Jiná situace však nastává, když vlastník takové komunikace současně nevlastní priiléhající veřejné osvětlení. Pokud tedy napríklad přes obec vede silnice II. třídy, její osvětlení musí zajistit primárně kraj, byt' veřejné osvětlení vlastní dotyčná obec“.

Podle výše uvedeného by se zdálo, že je legislativně všechno v pořádku. Ve skutečnosti se však dopravní prostor na průjezdních úsecích silnic $\mathrm{v}$ obcích $\mathrm{v}$ nočním prostředí noří do tmy. Města sice šetří, ale bohužel lidé umírají.

\section{Koncepční přístup $\mathrm{k}$ veřejnému osvětlení}

Při pohledu na osvětlený dopravní prostor města či obce je inned patrné, zda se jedná o rukopis koncepčního přístupu nebo zda se jednotlivé úseky komunikací osvětlují dle pravidel stanovených pro jednotlivou etapu rekonstrukce. Kvalitu veřejného osvětlení Ize s určitou nadsázkou prírovnat $\mathrm{k}$ uměleckému dílu. Pokud u uměleckého díla poznáte rukopis konkrétního umělce, má nejen svoji hodnotu, ale i uznání. Budete se mnou souhlasit, že obraz slepený z několika útržků od různých umělců by svou hodnotu neměl a pravděpodobně by se setkal i s velkou kritikou odborné i laické veřejnosti. Proč tomu tak není voblasti veřejného osvětlení, kde jde skutečně o životy, je zarážející. Pod tíhou tématu vlivu kvality osvětlení na dopravní nehodovost se však i tato skutečnost mění.

Prvními vlaštovkami jsou města a obce, která přistupují k veřejnému osvětlení koncepčním prístupem, jehož výsledkem je soubor schválených pravidel. Nemusí se jednat vždy pouze o určení množství světla pro každou komunikaci. Koncepční prístup může stanovit komplexní urbanistický vzhled veřejného osvětlení, pravidla pro plánovanou údržbu veřejného osvětlení ale i plánovanou obnovu a modernizaci veřejného osvětlení. Tato pravidla pak musí každý dodavatel dodržet a město se tak postupně přemění na umělecké dílo psané rukou „Světelného umělce".

\section{Vliv kvality veřejného osvětlení na dopravní nehodovost}

Rok 2013 nastartoval diskusi o vyhodnocení vlivu kvality veřejného osvětlení na dopravní nehodovost. Cílem průzkumu bylo vyhodnocení dopravních nehod na průjezdních úsecích silnic - tedy silnic I. až III. tříd v zastavěném území obcí. Důvodem je skutečnost, že na těchto úsecích jsou normy pro veřejné osvětlení závazné. Pracovní skupina „Osvětlení, bezpečnost, kriminalita" zpracovala celkem 3 analýzy. Výsledky všech třech analýz jednoznačně potvrdily významnou úlohu kvalitního veřejného osvětlení při zajištění bezpečného dopravního prostoru průjezdních úseků silnic měst a obcí v nočním prostředí s těmito závěry: 
- Zhoršením kvality veřejného osvětlení se zvyšuje dopravní nehodovost až o 121\%.

- Zvýšením kvality veřejného osvětlení se snižuje dopravní nehodovost až o 83\%.

- Využitím bílé barvy světla u kvalitního osvětlení se snižuje dopravní nehodovost až o 52\%.

Zdrojem informací pro analýzy se staly pouze základní informace o dopravních nehodách, které má ředitelství Služby dopravní policie policejního prezídia ČR [3]. Jednotlivé analýzy vyjadřují procentuální snížení dopravn nehodovosti po rekonstrukci veřejného osvětlení v porovnání ke stavu dopravní nehodovosti před rekonstrukcí veřejného osvětlení. Konkrétní prríčiny dopravních nehod zjišt'ovány nebyly.

Kvalita veřejného osvětlení souvisí i s odborností firem, které o veřejné osvětlení pečují. Nejlepší situace je ve městech, kde tuto službu zajišttují místní technické služby nebo profesionální soukromé společnosti. Nicméně je nutné podotknout, že i v těchto městech se již probouzejí politické snahy prosazující energetické úspory nad závazné normy. Statisícové úspory jsou tak stavěny nad hodnotu lidského života.

\section{Následky dopravních nehod}

Všeobecně známým pravidlem při srovnávání, je porovnávat porovnatelné a tento cíl si vytyčili i členové pracovní skupiny. Možností jak porovnat dopravní nehodovost mezi jednotlivými kraji je zajisté mnoho. Porovnat dopravní nehodovost Ize například podle:

a) počtu dopravních nehod,

b) následků dopravních nehod,

c) délky komunikací,

d) celkové intenzity dopravy za 24 hod,

e) intenzity dopravy $v$ průběhu dne,

f) velikosti měst a obcí, kterými průjezdní úseky silnic procházejí.

Jak je vidět $z$ výše uvedeného výčtu, metod pro porovnání lze vytvoriit více a to i vzájemnými kombinacemi. Porovnání by však mělo být jednoduše prezentovatelné a s použitím logického úsudku i pochopitelné a reprodukovatelné.

Při jednání se zástupci Ředitelství Služby dopravní policie Policejního prezidia ČR byla zvolena varianta vyhodnocení celkových následků dopravních nehod za rok 2014 na $1 \mathrm{~km}$ průjezdních úseků silnic.

Reditelství služby dopravní policie poskytlo statistiku dopravní nehodovosti a škod za rok 2014 na průjezdních úsecích silnic měst a obcí $v$ denním i nočním prostředí. Uvedená statistika za jednotlivé kraje je uvedena $v$ tabulce 1.

Na průjezdních úsecích silnic měst a obcí se za rok 2014 v ČR stalo celkem 28041 dopravních nehod. Na následky těchto dopravní nehod zemřelo celkem 146 osob a 985 osob bylo těžce zraněno. Výše škod odhadnutá dopravní policií se vyšplhala do výše 1,78 mld. Kč.

Pro výpočet celkových nákladů dopravních nehod byly využity informace 0 výši socioekonomických ztrát z dopravních nehod a jejich následků za rok 2012 zpracované Centrem dopravního výzkumu v.v.i [4]

- 1 usmrcená osoba 19022000 Kč,

- 1 těžce zraněná osoba 5001000 Kč,

- 1 lehce zraněná osoba 433000 Kč,

Celková výše následků dopravní nehodovosti dosáhla za rok 2014 částky 13,5 mld. Kč. Rozdělení následků dopravní nehodovosti za jednotlivé kraje je vyjádřeno v tabulce 1:

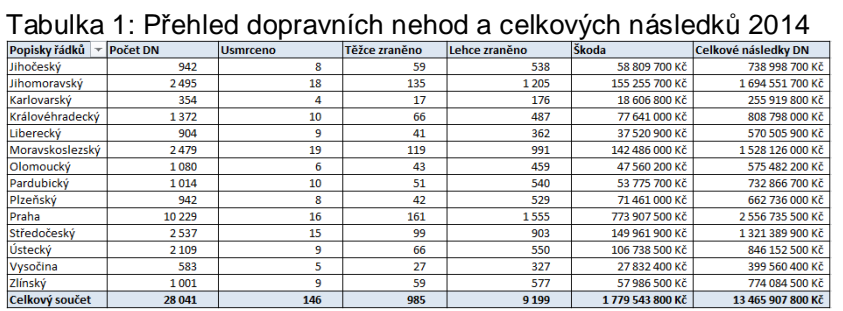

Pro zajištění možnosti vzájemného porovnání bylo nutné přepočítat celkové následky dopravních nehod na 1 kilometr délky průjezdních úseků silnic měst a obcí (viz tabulka 2). Délky komunikací k výslednému vyhodnocení poskytlo Reditelství silnic a dálnic ČR [5]. Pro hlavní město Praha nebylo toto přepočítání provedeno. Důvodem je odlišný systém evidence dopravních nehod, který se na území hlavního města Prahy používá

Tabulka 2: Celkové následky dopravních nehod na $1 \mathrm{~km}$ komunikace $v$ roce 2014

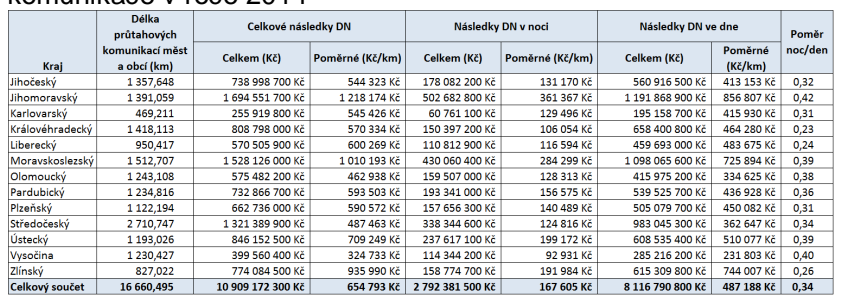

Graf 1: Celkové následky dopravních nehod na $1 \mathrm{~km}$ komunikace v roce 2014

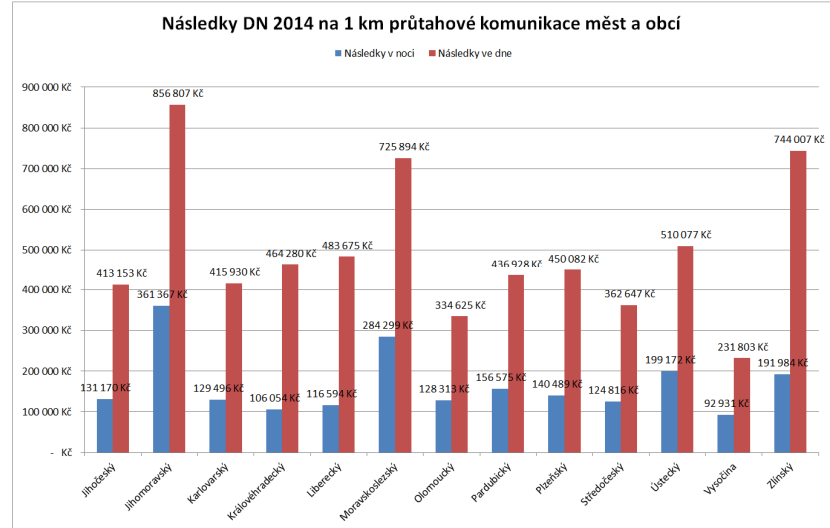

Následky dopravních nehod na jednom kilometru průjezdních úseků silnic měst a obcí (viz graf 1) dosahují $v$ noci třetinových následků dopravních nehod (167 tis. $\mathrm{Kč} / \mathrm{km}$ ) v porovnání s dopravními nehodami ve dne (487 tis. $\mathrm{Kč} / \mathrm{km})$. Nejhorší situace je $v$ Jihomoravském kraji, kde je tento poměr ve výši $42 \%$ (361 tis.Kč/km). Alarmující jsou také rozdíly celkových poměrných následků na $1 \mathrm{~km}$ komunikace. Celkové poměrné následky dopravních nehod v krajích se šplhají do výše 654 tis. Kč/km. Největších hodnot dosahuje Jihomoravský kraj a to konkrétně 1,2 mil. $\mathrm{Kč} / \mathrm{km}$ - rozdíl mezi kraji je téměř čtyřnásobný.

Společnost pro rozvoj veřejného osvětlení ve spolupráci s Ředitelstvím Služby dopravní policie Policejního prezídia ČR a oddělením BESIP Ministerstva dopravy ČR prezentuje téma vlivu kvality veřejného osvětlení na dopravní nehodovost $v$ rámci třetího ročníku Dopravních snídaní s BESIPem. Pro každý kraj byly vyhodnoceny následky dopravní nehodovosti pomocí matematického modelu, který určil úseky průjezdních úseků silnic s největšími následky. 
Pro vyhodnocení každé nehodové lokality v nočním prostředí je nejdříve nutné, řečeno odbornou terminologií, zatřídit nehodový úsek komunikace do třídy osvětlení a vyhodnotit úroveň hladiny osvětlení. Laicky řečeno - určit dle normy kolik světla má na komunikaci být a zjistit kolik světla na komunikaci ve skutečnosti je. Ruční zpracování by bylo velmi zdlouhavé a tak je pro tento záměr využíváno speciálního vozidla, které průjezdem osvětlené komunikace jednak definuje množství světla, které by mělo na dané komunikaci být (tzv. zatřídění příslušného úseku komunikace do třídy osvětlení dle ČSN EN 13 201), ale také určí úroveň splnění této normy. Jednoduše řečeno speciální vozidlo odhalí nejen místa, která mají nedostatek světla, ale také místa, která jsou přesvětlena.

Obrázek 1: Interiér měřícího vozidla

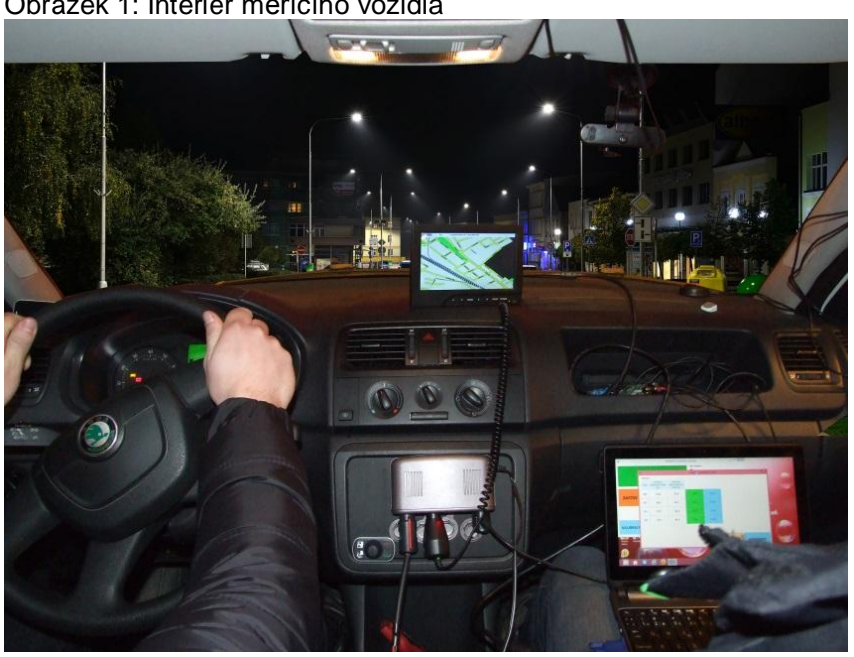

Dosavadní prověřené úseky

$\checkmark$ první polovině roku 2015 prověřila Společnost pro rozvoj veřejného osvětlení kvalitu osvětlení průjezdních úseků silnic ve 21 obcích. Průjezdní úseky silnic byly vybrány pomocí matematického modulu, který definoval lokality s nejvyššími následky dopravních nehod v roce 2014. Celkem byly na těchto úsecích při dopravních nehodách usmrceny 4 osoby, dále bylo zraněno 11 osob těžce a 27 osob lehce. S využitím ztrát z dopravní nehodovosti na pozemních komunikacích za rok 2013, které zveřejnilo Centrum dopravního výzkumu, v.v.i., se celková výše následků dopravních nehod na měřených lokalitách vyšplhala na 145 mil.Kč.

Výsledky kontroly kvality veřejného osvětlení průtahových úseků komunikací jsou alarmující. Z vyhodnocených úseků byly splněny normované hodnoty pouze ve 2 prípadech, v 7 prípadech byl průjezdní úsek silnice osvětlen maximálně do úrovně $50 \%$ normativního požadavku.
Tabulka 3: Kvallita veřejného osvětlení vyhodnocených lokalit

\begin{tabular}{|l|l|l|r|c|}
\hline \multicolumn{1}{|c|}{ Kraj } & \multicolumn{1}{|c|}{ Obec } & $\begin{array}{c}\text { třída } \\
\text { silnice }\end{array}$ & číslo silnice & $\begin{array}{c}\text { Úroveň } \\
\text { splnění } \\
\text { normy (\%) }\end{array}$ \\
\hline Moravskoslezský & Břidličná & II & 370 & $50 \%$ \\
\hline Moravskoslezský & Dolní Benešov & II & 56 & $56 \%$ \\
\hline Moravskoslezský & Dvorce & II & 46 & $40 \%$ \\
\hline Ústecký & Jirkov & III & 2525 & $59 \%$ \\
\hline Ústecký & Huntí̌ov & I & 13 & $60 \%$ \\
\hline Olomoucký & Dolní Studénky & III & 3703 & $49 \%$ \\
\hline Olomoucký & Medlov & II & 444 & $20 \%$ \\
\hline Pardubický & Žamberk & I & 11 & $80 \%$ \\
\hline Pardubický & Litomyšl & I & 35 & $75 \%$ \\
\hline Pardubický & Luková & III & 36818,36819 & $42 \%$ \\
\hline Jihočeský & Bernartice & II & 105 & $25 \%$ \\
\hline Jihočeský & Vimperk & II & 145 & $65 \%$ \\
\hline Jihočeský & Mladá Vožice & II & 124 & $25 \%$ \\
\hline Jihočeský & Veselí nad Lužnicí & II & 603 & $52 \%$ \\
\hline Královehradecký & Hořice & II & 300 & $69 \%$ \\
\hline Královehradecký & Hronov & III & 3031 & $47 \%$ \\
\hline Královehradecký & Jaroměř & I & 33 & $121 \%$ \\
\hline Plzeňský & Vejprnice & Ii & 203 & $55 \%$ \\
\hline Plzeňský & Líšina & II & 182 & $51 \%$ \\
\hline Plzeňský & Přeštice & I & 230 & $110 \%$ \\
\hline Plzeňský & Těchlovice & II & & \\
\hline & & & & \\
\hline
\end{tabular}

Z výsledků měření dále vyplývá, že kvalita veřejného osvětlení je závislá na důležitosti komunikace. Silnice I. třídy splňovaly normy v rozsahu od $50 \%$ do $121 \%$, silnice II. a III. trrídy pak pouze od $20 \%$ do $75 \%$ normované hodnoty.

\section{Závěr}

I přes závaznost norem veřejného osvětlení na průjezdních úsecích silnic, které jsou povinny při své činnosti respektovat právnické osoby, fyzické osoby i př́slušné orgány veřejné správy (viz § 169 zákona 183/2006 Sb.), nejsou mnohé nově rekonstruované soustavy veřejného osvětlení kvalitní, ba naopak. K chybnému osvětlení nejčastěji dochází v malých městech či obcích. Očividným důvodem této situace je skutečnost, že při rekonstrukcích veřejného osvětlení se staví úspory nad závaznost norem veřejného osvětlení, ve svém důsledku tedy nad lidský život.

Paradoxem celé této situace je skutečnost, že i když si projektanti závaznost norem veřejného osvětlení na průjezdních úsecích silnic uvědomí a budou projektovat veřejné osvětlení podle norem, přijde bohužel onen moment zákona o zadávání veřejných zakázek, kdy se nesmí do zadávací dokumentace napsat, které svítidlo projektant vybral. $V$ tomto velmi krátkém kroku je velmi důležitá práce projektanta znevážena a doslova vyhozena. Projektant společně se světelným technikem vybral z několika stovek variant vhodné svítidlo distribuující světelný tok do potřebných míst účelně a ekonomicky tedy jen proto, aby následně strpěl zahalení své práce jakousi anonymitou zadávací dokumentace. Z určitého pohledu je „otevřenost“ zadávací dokumentace pochopitelná, pokud by se však nepřehlížel nejdůležitějši moment, kterým je řádná kontrola při přebírání rekonstruovaného veřejného osvětlení. Poté, co se osvětlení postaví, totiž mnohé již nenapadne zkontrolovat, zda realizovaná stavba odpovídá normativním požadavkům, většině investorů postačí pouze fyzická kontrola provedené rekonstruované soustavy (jak jinak než ve dne!) a zejména pouhá revize, která o kvalitě veřejného osvětlení vypovídá pouze to, že po elektrické stránce je zařízení schopné bezpečného provozu. Zda jsou splněny závazné požadavky normy z hlediska osvětlenosti komunikace, již bohužel téměř nikoho nezajímá. Kolaudaci 
stavby Ize $v$ takovém prípadě přirovnat $k$ nákupu vysněného rodinného automobilu, kdy vám v prodejně předvedou auto vašich snů a při výdeji dostanete zcela jiný a nekvalitní automobil, taktéž ovšem se čtyřmi koly a jedním volantem!

Než dojde k proniknutí závaznosti norem veřejného osvětlení ke všem zodpovědným, budeme muset prihlížet ještě tisícům dopravních nehod se stovkami mrtvých a utrpením pozůstalých. Varovný hlas pracovní skupiny „Osvětlení, bezpečnost, kriminalita“ i dalších světelných odborníků na tento stav upozorňujících je stále silnější, ale proti „zajetému systému takzvaných úspor“ je prozatím jen zvednutým ukazováčkem, a to i přesto, že se již téměř každému řidiči toto „nepochopitelné nevidění“ chodce již stalo. Lidské oko je nejdůležitějším orgánem pro získáván informací, je však velmi citlivé na světlo a musí být tedy nejprve na dané osvětlené prostředí adaptováno. Bez kvalitně osvětleného dopravního prostoru nás tedy dokáže pořádně ošálit (až se nestačíme divit).
K řešení tohoto problému bude muset prispět pravděpodobně ještě nějaká mediální kauza, kdy se bude při soudním přelíčení prokazovat, zda řidičově oku byla dopřána adaptace na osvětlený dopravní prostor nebo zda nekvalitně nasvětlený prostor byl příčinou přehlédnutí osoby, kterou následně řidič usmrtil.

\section{REFERENCES}

[1] Zákon 183/2006, o územním plánování a stavebním rádu (stavební zákon)

[2] Vyhláška 104/1997, kterou se provádí zákon o pozemních komunikacích

[3] ředitelství Služby dopravní policie, data o dopravních nehodách na průjezdních úsecích silnic za rok 2014

[4] Centrum dopravního výzkumu, v.v.i, socioekonomické ztráty z dopravní nehodovosti za rok 2013

[5] Ředitelství dálnic a silnic, délky průjezdních úseků silnic a dálnic

Autor: Ing. Jiří Skála, Společnost pro rozvoj veřejného osvětlení, z.s. Pod Vysílačkou 1387, Praha 5, Zbraslav, Czech Republic, email:predseda@srvo.cz 